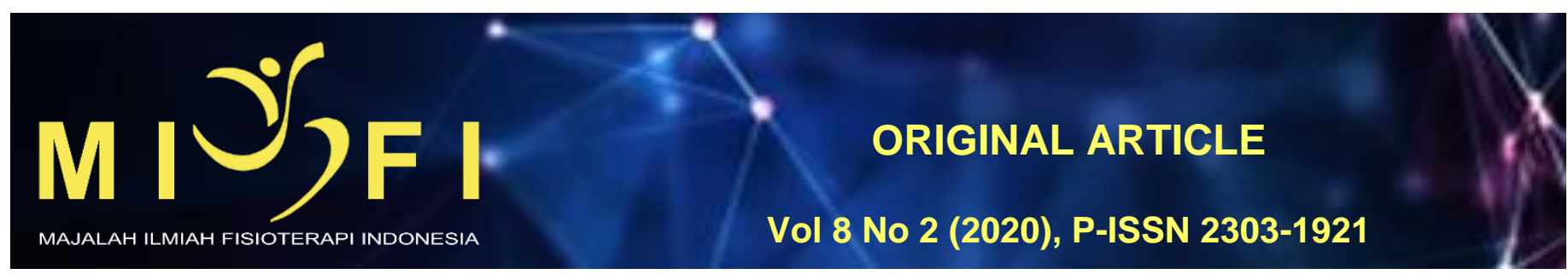

\title{
HUBUNGAN ASI EKSKLUSIF DENGAN TUMBUH KEMBANG BAYI USIA 0-12 BULAN DI PUSKESMAS II DENPASAR SELATAN
}

\author{
Ni Nyoman Melani Karang1, I Made Niko Winaya ${ }^{2}$, I Made Krisna Dinata ${ }^{3}$, Made Hendra Satria Nugraha ${ }^{2}$ \\ ${ }_{1}^{1}$ Program Studi Sarjana Fisioterapi dan Profesi Fisioterapi, Fakultas Kedokteran Universitas Udayana \\ ${ }^{2}$ Departemen Fisioterapi, Fakultas Kedokteran Universitas Udayana \\ ${ }^{3}$ Departemen IImu Faal, Fakultas Kedokteran Universitas Udayana \\ melanikarang9e27@gmail.com
}

\begin{abstract}
ABSTRAK
Salah satu nutrisi yang dibutuhkan oleh bayi selama 6 bulan pertama terdapat pada ASI, sehingga dirancanglah pemberian ASI eksklusif selama 6 bulan. Pemberian ASI eksklusif merupakan pemberian tanpa tambahan makanan maupun minuman. Air Susu Ibu (ASI) adalah cairan alamiah sebagai makanan sempurna bagi bayi khususnya berumur 0-6 bulan yang sangat dibutuhkan bagi pertumbuhan dan perkembangan optimal bayi.Tujuan dari penelitian ini ialah untuk mengetahui hubungan antara ASI eksklusif dengan tumbuh kembang bayi usia 0-12 bulan di Puskesmas II Denpasar Selatan. Jenis penelitian ini adalah observasional analitik dengan pendekatan cross sectional. Waktu penelitian dilaksanakan dari April-Mei 2019. Sampel penelitian sebanyak 88 bayi dengan teknik consecutive samlling. Pengumpulan data melalui checklist ASI eksklusif, pengukuran pertumbuhan menggunakan timbangan dan length board, untuk pengukuran perkembangan menggunakan DDST II (Denver Development Screening Test). Analisis data digunakan analisis univariat dan bivariat. Sampel pada penelitian ini sebanyak 88 orang (46 perempuan, 42 laki-laki) bayi usia 0-12 bulan. Diperoleh data bayi yang mendapatkan ASI eksklusif memiliki petumbuhan normal $66,1 \%$, kurus $18,5 \%$ dan gemuk 15,4\%. Sedangkan yang tidak mendapatkan ASI secara eksklusif memiliki pertumbuhan normal $39,1 \%$, kurus 17,4, gemuk 43,5\%. Bayi yang mendapatkan ASI eksklusif memiliki perkembangan normal 67,7\%, suspek $20,0 \%$ dan abnormal 12,3\%, bayi yang tidak ASI eksklusif memiliki perkembangan suspek 9,1\%, abnormal 26,1 \% dan normal 34,8\%. Hasil uji hipotesis yang digunakan ialah Chi Square Test dan Spearman's Rho untuk menganalisis signifikansi hubungan antara ASI eksklusif dengan pertumbuhan dan ASI eksklusif dengan perkembangan. Pada uji statistik, diketahui nilai $\mathrm{p}$ pada pertumbuhan ialah 0,018 serta $r=0,206$ dan nilai p perkembangan ialah 0,022 serta $r=0,283$ sehingga $p<0,05$. Berdasarkan hasil penelitian tersebut maka dapat disimpulkan bahwa terdapat adanya hubungan lemah, signifikan dan searah antara ASI eksklusif dengan pertumbuhan dan perkembangan bayi usia 0-12 bulan di Puskesmas II Denpasar Selatan.
\end{abstract}

Kata Kunci : ASI eksklusif, pertumbuhan, perkembangan

\section{THE RELATIONSHIP BETWEEN EXCLUSIVE BREASTFEEDING WITH THE GROWTH AND DEVELOPMENT OF INFANTS BETWEEN THE AGE OF 0-12 MONTHS IN PUSKESMAS II DENPASAR}

\section{ABSTRACT}

One of the nutrients required during the babies' first 6 six months is found in breast milk, therefore, an exclusive breastfeeding was designed. Exclusive Breastfeeding is given without any additional food or drink. Mother's breast milk is a natural liquid functions as perfect food for babies between 0-6 months required for the optimal growth and development of the baby. This study aims at finding the relationship between the exclusive breast feeding with the infants' growth and development between the age of 0-12 at the Puskesmas II Denpasar Selatan. The type of this study is analytical observation with cross sectional approach and conducted on April-May 2019. This study takes 88 infants (46 girl and 42 boy infants between the age 0-12) as sample by using consecutive sampling techniques and the data was collected by using ASI Ekslusif checklist, scale and length board to measure growth, the DDST II (Denver Development Screening Test) and was anlysed by using univariate and bivariate analysis. Data obtained from infants who received exclusive breastfeeding had normal growth of $66.1 \%$, thin $18.5 \%$ and fat $15.4 \%$. Whereas those who are not exclusively breastfed had normal growth of $39.1 \%$, thin $17.4 \%$, and fat $43.5 \%$. Babies who are exclusively breastfed have normal development of $67.7 \%$, suspect $20.0 \%$ and abnormal $12.3 \%$, infants without exclusive breastfed have suspected development of $9.1 \%$, abnormal $26.1 \%$ and normal 34,8\%. The hyphotesis used is Chi Square Test and Spearman's Rho to analyze the significance of the relationship between exclusive breastfeeding and growth and development. In the statistical test, it is known that the value of $p$ in growth is 0.018 and $r=0.206$ and the developmental $p$ value is 0.022 and $r=0.283$ so that $p<0.05$. It can be concluded that there is a weak, significant and unidirectional relationship between exclusive breastfeeding and the growth and development of infants between the age of 0-12 months in Puskesmas II Denpasar Selatan.

Keywords : exclusive breastfeeding, growth, development 


\section{PENDAHULUAN}

Tahun pertama merupakan usia yang penting dalam tumbuh dan kembang seorang bayi. Usia perkembangan tahun pertama dapat dibedakan menjadi 2 yaitu, neonatus sejak lahir sampai usia 28 hari dan bayi dari usia 29 hari sampai 12 bulan. Dalam periode 1000 hari pertama kehidupan (window of opportunities) atau golden period, didasarkan pada masa janin hingga anak berusia dua tahun yang mengalami proses tumbuh kembang yang sangat cepat dan tidak ditemukan pada kelompok usia lain ${ }^{1}$.Nutrisi yang baik dan diperlukan selama periode 1000 hari kehidupan sangat berguna untuk masa depan kesehatan, kesejahteraan dan kesuksesan anak. ASI eksklusif merupakan ASI yang diberikan kepada bayi sejak dilahirkan selama 6 bulan, tanpa menambahkan dan atau mengganti dengan makanan atau minuman lain?2.

Tumbuh kembang adalah proses yang saling berkaitan satu sama lain dan sulit dipisahkan yaitu pertumbuhan dan perkembangan. Pertumbuhan (growth) merupakan perubahan yang bersifat kuantitatif, yaitu dengan bertambahnya jumlah, ukuran, dimensi pada tingkat sel, organ, maupun individu ${ }^{3}$. Sedangkan perkembangan menyangkut proses diferensiasi sel tubuh, jaringan, organ maupun sistem organ yang berkembang dengan sedemikian rupa. Perkembangan meliputi proses perkembangan kognitif, bahasa, motorik, dan perilaku sebagai hasil interaksi dengan lingkungannya ${ }^{3,4}$. Pertumbuhan dan perkembangan anak dapat dipengaruhi oleh faktor internal dan eksternal. Salah satu faktor eksternal yang memiliki andil besar dalam pertumbuhan dan perkembangan bayi adalah Gizi. Gizi memiliki peranan penting dalam pertumbuhan dan perkembangan bayi, sehingga perlu untuk memberikan nutrisi yang paling baik sejak awal kehidupannya ${ }^{5}$

Memberikan ASI eksklusif kepada bayi dan menunda untuk memberikan makanan pendamping akan menurunkan resiko bayi terkena alergi makanan ${ }^{6}$. Berdasarkan hasil yang diperoleh oleh SDKI pada 2012 gangguan tumbuh kembang anak-anak Indonesia disebabkan oleh ketidak patuhan dalam pemberian ASI eksklusif pada bayi. Pertumbuhan dan perkembangan akan mengakibatkan terjadinya peningkatan kemampuan suatu individu terutama pada kemampuan otak yang mulai berkembang. Berdasarkan Profil Kesehatan Kota Denpasar tahun 2017 cakupan pemberian ASI eksklusif sebesar 47,65\% sudah mengalami peningkatan bila dibandingkan tahun 2016. Target ASI eksklusif tahun 2017 sebesar $43 \%$ sehingga kota Denpasar sudah mencapai target yang ditetapkan. Meskipun secara umum di Kota Denpasar terjadi peningkatan cakupan ASI eksklusif, namun hasil tersebut masih perlu ditingkatkan. Cakupan ASI eksklusif di Puskesmas II Denpasar Utara sebesar 52,8\%, Puskesmas II Denpasar Timur 44,9\% sedangkan cakupan ASI eksklusif di Puskesmas II Denpasar Barat sebesar 50,35\%. Untuk cakupan ASI eksklusif terendah terdapat di Puskesmas II Denpasar Selatan sebesar 41,47\%, sehingga perlu adanya berbagai upaya yang mampu meningkatkan capaian ASI eksklusif di Kota Denpasar sehingga bisa mencapai target yang ditetapkan. Upayaupaya untuk meningkatkan pemberian ASI eksklusif perlu terus dilaksanakan dengan memberikan penyuluhan dan bimbingan kepada ibu hamil tentang cara perawatan payudara dan menyusui yang baik sehingga mereka dapat melaksanakan program AS eksklusif. Masih rendahnya angka pemberian AS eksklusif ini dipengaruhi oleh banyak faktor, salah satunya faktor bayi seperti ketidakmampuan untuk menerima ASI (kelainan bawaan), tidak dilakukan inisiasi menyusui dini saat melahirkan, waktu tidak sepenuhnya bersama bayi, perkembangan kelenjar mammae maupun sekresi hormon prolaktin dan oksitosin tidak adekuat. Menyusui pada hari-hari pertama kehidupan memberikan bayi baru lahir kolostrum yang kaya akan nutrisi, antibodi yang penting untuk perkembangan mikrobiota usus dan sistem kekebalan tubuh.

\section{METODE}

Penelitian ini merupakan penelitian cross sectional analytic yang menggunakan 88 subjek bayi berusia 0-12 bulan di Puskesmas II Denpasar Selatan. Penelitian ini dilaksanakan pada bulan April-Mei 2019. Subjek penelitian dipilih melalui consecutive sampling yang sebelumnya telah memenuhi kriteria inklusi diantaranya, merupakan ibu sampel bersedia secara sukarela menjadi respoden dari awal penelitian sampai akhir dengan menandatangani informed consent, bayi sudah mendapatkan imunisasi sesuai usia serta dapat kooperatif dan bersedia mengikuti penelitian. Sedangkan kriteria eksklusi berupa bayi yang memiliki cacat bawaan. Untuk kriteria drop out responden tidak memberikan data dengan lengkap.

Variabel independen pada penelitian ini adalah ASI eksklusif diketahui melalui checklist ASI eksklusif. Sedangkan variabel dependen pada penelitian ini yaitu pertumbuhan dan perkembangan, dimana variabel pertumbuhan diketahui melalui pengukuran yang menggunakan standar antropomentri dengan mengukur status gizi dari bayi. Pertumbuhan dilihat berdasarkan BB/PB dengan pengukuran langsung, untuk berat badan diukur dengan timbangan dan panjang badan menggunakan lenght board, yang dikategorikan menurut Kepmenkes yaitu kurus, normal, gemuk. Untuk perkembangn pada variabel dependen diketahui melalui Denver Development Screening Test (DDST) II yang dikategorikan manjadi normal, suspek, abnormal.

Setelah data diperoleh akan dilakukan pengolahan melalui yang diuji dengan Chi Square Test dan Spearman rho untuk mengetahui hubungan dan kekuatan kolerasi antara ASI eksklusif dengan pertumbuhan serta ASI eksklusif dengan perkembangan bayi usia 0-12 bulan.

\section{HASIL}

Penelitian ini mendata 88 subjek bayi berusia 0-12 bulan. Adapun karakteristik subjek berdasarkan usia, jenis kelamin, ASI eksklusif, pertumbuhan dan perkembangan dapat dilihat pada tabel berikut ini : 
Tabel 1. Distribusi Frekuensi Karakteristik Subjek Penelitian berdasarkan Jenis Kelamin, ASI eksklusif, Pertumbuhan dan Perkembangan

\begin{tabular}{lcc}
\hline \multicolumn{1}{c}{ Karakteristik } & Frekuensi & Presentase (\%) \\
\hline Jenis Kelamin & & \\
\hline Laki-laki & 42 & 47,7 \\
Perempuan & 46 & 52,3 \\
ASI Eksklusif & & \\
Non ASI Eksklusif & 23 & 26,1 \\
ASI Eksklusif & 65 & 73,9 \\
\hline Pertumbuhan & & \\
\hline Kurus & 16 & 18,2 \\
Normal & 52 & 59,1 \\
Gemuk & 20 & 22,1 \\
\hline Perkembangan & & \\
\hline Normal & 52 & 59,1 \\
Abnormal & 14 & 15,9 \\
Suspek & 22 & 25 \\
\hline
\end{tabular}

Berdasarkan Tabel 2 dapat dilihat mayoritas subjek penelitian adalah perempuan sebesar 52,3 \%. Kategori pemberian ASI eksklusif mayoritas sebesar 73,9\% dibandingkan Non ASI eksklusif. Untuk kategori pertumbuhan subjek penelitian lebih banyak memiliki pertumbuhan normal yaitu 59,1\% dan perkembangan yang normal sebesar 59,1\%. Serta didapatkan rata-rata usia pada penelitian ini adalah 7,3977 dengan standar deviasi $\pm 3,2573$.

Tabel 2. Hubungan ASI Eksklusif dengan Pertumbuhan

\begin{tabular}{cccccc}
\hline \multirow{2}{*}{ ASI } & \multicolumn{5}{c}{ Pertumbuhan } \\
\cline { 2 - 4 } & Kurus & Normal & Gemuk & \multirow{2}{*}{$\mathbf{p}$} & $\mathbf{r}$ \\
\cline { 2 - 4 } & $\mathbf{n}(\%)$ & $\mathbf{n ~ ( \% )}$ & $\mathbf{n}(\%)$ & & \\
\hline Non ASI & 4 & $9(39,1)$ & 10 & & \\
Eksklusif & $(17,4)$ & $93,5)$ & 0,018 & 0,206 \\
ASI & 12 & 43 & 10 & & \\
Eksklusif & $(18,5)$ & $(66,2)$ & $(15,4)$ & & \\
\hline
\end{tabular}

Berdasarkan Tabel 2 bayi yang mendapat ASI eksklusif memiliki pertumbuhan normal sebesar 43 orang (66,2\%), kurus 12 orang (18,5\%), dan gemuk 10 orang (43,5\%). Sedangkan bayi yang tidak mendapatkan ASI secara eksklusif mengalami pertumbuhan normal sebesar 9 orang $(39,1 \%)$, kurus 4 orang $(17,4 \%)$ dan gemuk 10 orang (15,4\%). Dari tabel tersebut menunjukan bahwa terdapat hubungan bermakna antara ASI eksklusif dengan Pertumbuhan yaitu $p=0,018$ dan $r=0,206$. Didapatkan $r$ sebesar 0,206 yang menunjukkan dengan pemberian ASI secara eksklusif pertumbuhan akan semakin normal. Hal ini berarti bahwa terdapat hubungan lemah, signifikan dan searah antara ASI Eksklusif dengan Pertumbuhan.

Tabel 3. Hubungan ASI Eksklusif dengan Perkembangan

\begin{tabular}{ccccccc}
\hline \multirow{2}{*}{ ASI } & \multicolumn{3}{c}{ Perkembangan } & & \multirow{2}{*}{$\mathbf{p}$} & \multirow{r}{*}{$\mathbf{r}$} \\
\cline { 2 - 4 } & Normal & Abnomal & Suspek & & & \\
\cline { 2 - 4 } & $\mathrm{n}(\%)$ & $\mathrm{n}(\%)$ & $\mathrm{n}(\%)$ & & \\
\hline Non ASI Eksklusif & $8(34,8)$ & $6(26,1)$ & $9(39,1)$ & \multirow{2}{*}{0,022} & 0,283 \\
ASI Eksklusif & $44(67,7)$ & $8(12,3)$ & $13(20,0)$ & & \\
\hline
\end{tabular}

Berdasarkan Tabel 3 bayi yang mendapat ASI eksklusif memiliki perkembangan normal sebesar 44 orang $(67,7 \%)$, abnormal 8 orang $(12,3 \%)$, dan suspek 13 orang $(20,0 \%)$. Sedangkan bayi yang tidak mendapatkan ASI secara eksklusif mengalami perkembangan normal sebesar 8 orang $(34,8 \%)$, abnormal 6 orang $(26,1 \%)$ dan suspek 9 orang $(39,1 \%)$. Dari tabel tersebut menunjukan bahwa terdapat hubungan bermakna antara ASI eksklusif dengan Pertumbuhan yaitu $p=0,022$ dan $r=0,283$. Diperoleh hasil $r$ sebesar 0,283 yang menunjukkan dengan pemberian ASI secara eksklusif maka perkembangan akan normal. Hal ini berarti bahwa terdapat hubungan lemah, signifikan dan searah antara ASI eksklusif dengan Perkembangan.

\section{DISKUSI \\ Karakteristik Subjek Penelitian}

Berdasarkan data yang diperoleh informasi mengenai rata-rata usia pada penelitian ini sebesar 7,3977 dengan standar deviasi $\pm 3,2573$. Karakterisik subjek penelitian berdasarkan pada jenis kelamin didapatkan mayoritas jenis kelamin subyek penelitian adalah perempuan yaitu 46 orang $(52,3 \%)$ sedangkan untuk subjek penelitian berjenis kelamin laki-laki diperoleh 42 orang $(47,7 \%)$. Total subjek penelitian sebanyak 88 bayi berusia $0-12$ bulan yang telah memenuhi kriteria.

Berdasarkan data peneliyian yang telah dilakukan subjek penelitian mayoritas mendapatkan ASI eksklusif sebanyak 65 orang (73,9\%) dan sisanya tidak mendapatkan ASI secara eksklusif 23 orang (26,1\%). Didukung oleh data RISKESDAS pada tahun 2018 yang menyatakan bahwa adanya peningkatan status gizi pada balita sebesar 6,4 $\%$. Hal tersebut karena terdapat peran tenaga kesehatan dalam kualitas kesehatan yaitu dengan meningkatkan pengetahuan orangtua mengenai pentingnya ASI bagi pertumbuhan dan perkembangan bayi ${ }^{8}$. 
Dari hasil penelitian diperoleh bahwa pertumbuhan normal lebih banyak yaitu sebesar 52 orang (59,1\%), diikuti pertumbuhan kurus sebesar 16 orang (18,2\%) dan gemuk 20 orang $(22,7 \%)$. Sesuai dengan hasil RISKESDAS tahun 2018 yang memperlihatkan bahwa terjadi penurunan status gizi kurus dan gemuk pada balita sebesar 1,9\%. Hal tersebut karena dipengaruhi oleh beberapa faktor diantaranya genetik dan lingkungan?.

Hasil penelitian yang telah dilakukan didapatkan informasi bahwa perkembangan normal pada subjek penelitian lebih banyak yaitu sebesar 52 orang (59,1\%) diikuti perkembangan suspek 22 orang (25,0\%) dan abnormal 14 orang (15,9\%). Hal ini disebabkan oleh beberapa faktor seperti faktor genetik dan lingkungan. Faktor genetik memainkan peran penting dalam memengaruhi perkembangan balita. Dikarenakan dari potensi genetik yang baik dapat berinteraksi positif dengan lingkungan sehingga berdampak terhadap pertumbuhan dan perkembangan yang optimal ${ }^{3}$. Faktor lingkungan seperti nutrisi, stimulasi, perawatan kesehatan juga berdampak bagi pertumbuhan dan perkembangan bayi. ASI adalah makanan ideal dan terbaik untuk bayi dimana memiliki kandungan protein, karbohidrat dan lemak yang dibutuhkan untuk pertumbuhan dan perkembangan. Bayi yang mendapat ASI eksklusif kecil kemungkinan mengalami obesitas. Hal tersebut karena ASI eksklusif hingga usia 6 bulan dapat membantu dalam meningkatkan kesehatan dan perkembangan anak. Perawatan kesehatan juga memiliki peran penting dalam pertumbuhan dan perkembangan yang mana pemberian imunisasi dapat meningkatkan kualitas kesehatan dengan cara mencegah timbulnya penyakit dan meningkatkan sistem kekebalan tubuh ${ }^{3,9,10}$.

\section{Hubungan ASI Eksklusif dengan Pertumbuhan}

Berdasarkan hasil penelitian dengan uji statistik Chi Square hasil yang diperoleh bayi yang mendapat ASI eksklusif memiliki pertumbuhan normal sebesar 43 (66,2\%), kurus 12 (18,5\%), dan gemuk 10 (15,4\%). Sedangkan bayi yang tidak mendapatkan ASI secara eksklusif mengalami pertumbuhan normal sebesar 9 (39,1\%), kurus 4 (17,4\%) dan gemuk 10 (43,3\%). Berdasarkan hasil tersebut menunjukan bahwa terdapat hubungan lemah, signifikan dan searah antara ASI eksklusif dengan pertumbuhan yaitu dengan $p=0,018$ dan $r=0,206$.

Pada penelitian yang telah dilakukan oleh Sandewi pada tahun 2018 dengan jumlah responden sebanyak 78 orang yang berusia 7-12 bulan di wilayah Kerja Puskesmas Poasia diperoleh nilai $p=0,000$ dimana terdapat hubungan antara pemberian ASI Eksklusif dengan pertumbuhan pada bayi ${ }^{11}$. Didukung hasil penelitian yang dilaksanakan di Polindes Ngumpul Kec. Jogoroto Kab. Jombang oleh Nawangsari terdapat hubungan yang bermakna antara pemberian ASI eksklusif dengan pertumbuhan bayi usia 0-6 bulan dimana $p=(0,017)(p<0,05)$, menyatakan pemberian ASI secara eksklusif dapat mencukupi kebutuhan nutrisi yang perlukan tubuh untuk pertumbuhan bayi usia 0-6 bulan ${ }^{12}$. ASI memiliki sumber gizi yang sangat ideal dan komposisi yang seimbang serta sesuai dengan kebutuhan pertumbuhan bayi. Selain itu ASI mempunyai kuantitas maupun kualitas paling sempurna untuk bayi13. Pemberian ASI secara eksklusif dapat mencukupi kebutuhan nutrisi yang diperlukan selama pertumbuhan bayi, sedangkan pemberian susu formula bila tidak sesuai dengan takaran maka berakibat buruk pada kesehatan seperti kekurangan gizi atau terjadi obesitas. Sejalan penelitian yang dilakukan oleh Ara,et al., tahun 2015 ditemukan bayi yang tidak disusui secara eksklusif memiliki risiko 4,321 kali lebih tinggi untuk menderita pertumbuhan yang buruk ${ }^{14}$.

ASI mengandung karbohidrat (laktosa) yang berperan sebagai sumber kalori dalam ASI yang diserap oleh tubuh sesuai dengan kebutuhan bayi. Rasio protein whey dan kasein dalam ASI adalah 60:40, sedangkan susu sapi memiliki rasio sebesar 20:80. Terdapat kandungan protein dalam ASI yaitu protein whey dan kasein, protein whey yang terdapat pada susu sapi mengandung beta laktoglobulin yang sering menyebabkan alergi. Protein whey dalam ASI lebih mudah diserap dibandingkan protein kasien. Dalam susu sapi kandungan karbohidrat dan lemak menghasilkan kalori yang tinggi sehingga bayi berisiko mengalami obesitas. ASI mengandung insulin dan leptin yang dapat mengatur metabolisme lemak dan karbohidrat dalam tubuh sehingga bayi yang disusui memiliki berat dan panjang sesuai dengan kurva pertumbuhan WHO bila dibandingkan dengan bayi yang diberi susu formula, atau campuran bayi yang disusui dan susu formula ${ }^{15,16}$. Selain tedapat karbohirat, lemak dan protein ASI mengandung sitokin dan faktor pertumbuhan yang memainkan peran penting dalam mempersiapkan sistem kekebalan tubuh bayi ${ }^{17}$.

\section{Hubungan ASI Eksklusif dengan Perkembangan}

Berdasarkan hasil penelitian dengan uji statistik Chi Square didapatkan hasil bahwa bayi yang mendapat ASI eksklusif memiliki perkembangan normal sebesar 44 (67,7\%), abnormal 8 (12,3\%), dan suspek 13 (20,0\%). Sedangkan bayi yang tidak mendapatkan ASI secara eksklusif mengalami perkembangan normal sebesar 8 (34,8\%), abnormal 6 $(26,1 \%)$ dan suspek $9(39,1 \%)$. Berdasarkan data tersebut menunjukan bahwa terdapat hubungan lemah, signifikan dan serarah antara ASI eksklusif dengan perkembangan yaitu dengan $p=0,022$ dan $r=0,283$.

Hasil ini serupa dengan penelitian yang dilakukan oleh Bahrudin tahun 2016 di Poli Tumbuh Kembang RSUD Sidoarjo menunjukkan bahwa ada hubungan antara pemberian ASI eksklusif dengan perkembangan bayi usia 6 bulan -1 tahun dengan nilai $p=0,034(p<0,05)^{18}$. Maka dari itu pemberian ASI eksklusif diharapkan bayi akan memiliki perkembangan yang normal, sedangkan bayi yang tidak mendapatkan ASI secara eksklusif akan berpotensi mengalami gangguan perkembangan. Perkembangan bayi yang tidak diberi ASI secara eksklusif memiliki risiko 3,818 kali lebih tinggi untuk mengalami perkembangan yang buruk menurut penelitian yang dilakukan oleh Ara,et al., tahun $2015^{14}$. Sejalan dengan penelitian yang dilakukan oleh Puteri dengan nilai signifikan $p=0,007(p<0,05)$, pemberian ASI eksklusif selama 6 bulan yang dilanjutkan hingga usia 2 tahun dapat memenuhi kebutuhan fisik-biomedis (asuh), kebutuhan kasih sayang (asih), dan kebutuhan stimulasi (asah) ${ }^{19}$. Dengan memenuhi kebutuhan dasar anak baik kebutuhan fisikbiomedis, kebutuhan emosi atau kasih sayang dan kebutuhan akan stimulasi dapat menunjang pertumbuhan dan perkembangan yang lebih baik ${ }^{3}$.

ASI merupakan komponen yang sempurna untuk bayi, pada ASI sendiri memiliki berbagai manfaat yang berguna bagi perkembangan ${ }^{13}$. Pemberian ASI secara eksklusif selama 6 bulan kepada bayi dapat mempengaruhi perkembangan baik itu perkembangan kognitif, bahasa, perilaku sosial ${ }^{20}$. Konsentrasi tinggi n3-PUFA dan ratio tinggi 
n3-n6 PUFA terdapat pada kolustrum payudara lbu. Pada bayi yang mendapatkan ASI secara eksklusif selama 6 bulan atau lebih dapat berpengaruh pada perkembangan motorik, hal ini dikarenakan oleh efek biokimia21. Bayi yang mendapatkan ASI eksklusif akan mencapai kemampuan motorik yang lebih baik dibandingkan bayi yang tidak mendapatkan ASI secara eksklusif. ASI memiliki kandungan lemak omega 3 dan omega 6 yang berfungsi untuk perkembangan otak bayi ${ }^{16}$. Komponen $\mathrm{Hsc} / \mathrm{p} 70$ yang terdapat pada ASI melindungi materi putih sel otak dari kematian (apoptosis) dan kandungan tersebut yang dapat mengurangi gangguan pada perkembangan baik perkembangan motorik, bahasa, kognitif, dan kecerdasan perilaku²2. LCPUFA yang terdapat pada ASI dapat mempengaruhi struktur dan fungsi membran sel yang merupakan asam lemak utama untuk otak dan retina ${ }^{3}$. ASI juga mengandung faktor pertumbuhan tiroksin dan saraf serta asam lemak seperti DHA dan AA yang berperan terhadap perkembangan kognitif serta perkembangan jaringan saraf dan retina mata 13,16. Selain itu DHA yang terkandung dalam ASI dapat mempengaruhi perkembangan bahasa bayi serta pemberian ASI secara eksklusif dapat menyempurnakan perkembangan motorik pada bayi. lbu yang menyusui secara eksklusif memiliki kekhawatiran lebih rendah mengenai perkembangan bahasa dan motorik kasar serta halus pada bayinya daripada ibu yang tidak menyusui secara eksklusif ${ }^{23}$. Selain gizi, stimulasi juga dapat berpengaruh pada perkembangan. Stimulasi yang dapat diberikan seperti stimulasi motorik, bahasa, sosial. Anak mendapatkan stimulasi sosial dengan cara berkumpul bersama orang sekitarnya selain itu saat ibu menyusui ibu dapat bercengkram dengan bayinya, hal tersebut dapat mempengaruhi perkembangan bayi tersebut ${ }^{24}$.

Penelitian selanjutnya disarankan untuk mengontrol faktor - faktor yang berkaitan seperti BBBL, stimulasi, pendidikan orang tua, pendapatan orang tua serta jumlah anak dalam keluarga tersebut.

\section{SIMPULAN}

Berdasarkan penelitian yang telah dilaksanakan mengenai Hubungan ASI Eksklusif dengan Tumbuh Kembang

Bayi Usia 0-12 Bulan di Puskesmas II Denpasar Selatan dapat disumpulkan bahwa

1. Terdapat hubungan yang lemah, signifikan dan searah antara ASI Eksklusif dengan Pertumbuhan

2. Terdapat hubungan yang lemah, signifikan dan searah antara ASI Eksklusif dengan Perkembangan

\section{DAFTAR PUSTAKA}

1. Depkes. 2012. Penuhi Kebutuhan Gizi Pada 1000 Hari Pertama Kehidupan. Jakarta: Departemen Kesehatan Republik Indonesia.

2. Depkes. 2012. Peraturan Pemerintah Republik Indonesia Nomor 33 Tahun 2012 Tentang Pemberian Air Susu Ibu Eksklusif. Jakarta: Kementrian Kesehatan RI

3. Soetjiningsih and Ranuh, IG. 2013. Tumbuh Kembang Anak. 2nd ed. Jakarta: EGC

4. Almatsier, S. 2012. Prinsip Dasar IImu Gizi. Jakarta: PT Gramedia Pustaka Utama

5. Tanuwidjaya S. 2002. Buku Ajar Ilmu Tumbang Anak. Jakarta: IDAI

6. Prasetyono, D.S. 2009. ASI Eksklusif Pengenalan, Praktik dan Kemanfaatannya. Yogyakarta: Diva Press

7. Riskesdas. 2018. Hasil Utama Riskesdas 2018. Kementrian Kesehatan Republik Indonesia

8. Depkes. 2014. InfoDATIN Situasi dan Analisis Asi Eksklusif. Jakarta: Kementrian Kesehatan RI

9. Pem, D. 2015. Factors Affecting Early Childhood Growth and Development: Golden 1000. Journal of Advanced Practices in Nursing Pem, Adv Practice Nurs. Faculty of Nursing and Public Health, Khesar Gyalpo University of Medical Sciences of Bhutan

10. Pusat Pendidikan dan Pelatihan Tenaga Kesehatan. 2014. Buku Ajar Imunisasi. Jakarta: Pusat Pendidikan dan Pelatihan Tenaga Kesehatan

11. Sandewi, S. 2018. Hubungan Pemberian Asi Eksklusif Dengan Pertumbuhan Dan Perkembangan Pada Bayi Usia 7-12 Bulan Di Wilayah Kerja Puskesmas Poasia Tahun 2018. Kendari:Politeknik Kesehatan Kendari

12. Nawangsari, H. 2015. Hubungan Antara Pemberian Asi Eksklusif Dengan Pertumbuhan Bayi Usia 0-6 Bulan Studi Di Polindes Ngumpul Kec. Jogoroto Kab. Jombang. Midwifery Journal of STIKES Insan Cendekia Medika Jombang, 10(1): 43-45

13. Roesli, U. 2009. Mengenal ASI Eksklusif. Jakarta, Trubus Agriwidya: 3-12

14. Maida AA, Surdaryati E, Lubis Z.2018. Infant's Growth and Development at the Age of 6-12 Months Based on Breasfeeding. International Journal of Public Health Science (IJPHS) 7(2): 120-129

15. Bayyenat S, Hashemi S, Purbafrani A, Saeidi M. 2014. The Importance of Breastfeeding in Holy Quran. International Journal of Pediatrics, 2(4).

16. Hendarto, A and Pringgadini, K. 2008. Nilai Nutrisi Air Susu Ibu. In : IDAI. Bedah ASI : Kajian dari Berbagai Sudut Pandang IImiah. Jakarta: Balai Penerbit FK UI.

17. Prasetyawati, A.E. 2012. Kesehatan Ibu dan Anak (KIA). Yogyakarta: Nuha Medika

18. Bahrudin, M. 2016. Hubungan Pemberian ASI Eksklusif dengan Perkembangan Bayi Usia 6 bulan - 1 tahun. Jurnal Penelitian Kesehatan Suara Forikes, 7(2): 77-78

19. Puteri, A.D. 2018. Hubungan Pemberian Asi Eksklusif Dengan Perkembangan Bayi Usia 3-6 Bulan Di Wilayah Kerja Puskesmas Bangkinang Tahun 2018. PREPOTIF Jurnal Kesehatan Masyarakat 2(1):28-34

20. Choi HJ, Kang SK, Chung MR. 2018. The relationship between exclusive breastfeeding and infant development:A 6-and12-month follow-up study. Early Human

21. McCrory, C and Murray, A. 2012. The Effect of Breastfeeding on Neuro-Development in Infancy. Matern Child Health J 17:1680-1688

22. Suryawan, A. 2015. Peran menyusui dalam pencegahan gangquan perkembangan akibat kerusakan white matter otak pada bayi prematur; dalam breastfeeding sick babies. Jakarta 
23. Dee D, MD Ruowel, Lee LC, Strawn LMG. 2007. Associations0Between0Breastfeeding0Practices and Young Children's Language and Motor Skill Development. PEDIATRICS 119: 96-97

24. Sakinah N, Andayani NLN, Dinata IMK.2017.Perbedaan Tingkat Perkembangan Bayi Yang Diberi Asi Eksklusif Dan Non Eksklusif Di Wilayah Kerja Puskesmas Padang Karambia Kecamatan Payakumbuh Selatan. Majalah IImiah Fisioterapi Indonesia, 5(3): 45-47 